\title{
Photosynthesis-irradiance relationships of antarctic phytoplankton during austral winter
}

\author{
Ross I. Brightman*, Walker O. Smith, Jr** \\ Graduate Program in Ecology, University of Tennessee, Knoxville, Tennessee 37996, USA
}

\begin{abstract}
Results from photosynthesis-irradiance (P-I) experiments were used to examine photosynthetic adaptations of phytoplankton populations from the Bransfield Strait region in Antarctica during austral winter. Chlorophyll a concentrations during this period were low, ranging from 0.04 to $0.33 \mu \mathrm{g} \mathrm{I}^{-1}$ in the mixed layer. Average photosynthetic efficiency $(\alpha)$ for surface populations was 0.021 $\mathrm{mg} \mathrm{C}(\mathrm{mg} \mathrm{chl})^{-1} \mathrm{~h}^{-1}\left(\mu \mathrm{E} \mathrm{m}^{-1} \mathrm{~s}^{-1}\right)^{-1}( \pm 0.01)$, and mean maximum photosynthetic rates $\left(\mathrm{P}_{\mathrm{m}}^{\mathrm{B}}\right)$ were $1.19 \mathrm{mg}$ $\mathrm{C}(\mathrm{mg} \mathrm{chl})^{-1} \mathrm{~h}^{-1}( \pm 0.6)$. No apparent differences were found between photosynthetic parameters for open ocean regions or within the Bransfield Strait, and there was little evidence for adaptation within the water column. Integrated production within the euphotic zone was low, 1 to $7 \mathrm{mg} \mathrm{C} \mathrm{m}-2 \mathrm{~d}^{-1}$, when estimated either from in situ measurements or from P-I relationships. These low primary productivity values support the belief that the waters within the Antarctic remain a region of extremely low productivity during the winter, despite conditions such as water column stratification and saturating surface irradiance levels which could potentially support phytoplankton growth.
\end{abstract}

\section{INTRODUCTION}

Photosynthetic responses of phytoplankton have been shown to change in response to fluctuations in ambient irradiance on a variety of time scales. Estimates of photosynthesis of a single population at a range of light intensities (P-I curves) have been made in a variety of environments (e.g. Jassby \& Platt 1976, Lewis \& Smith 1983, Harrison et al. 1985, Harrison \& Platt 1986) and have provided information on the productivity patterns and photosynthetic parameters of phytoplankton, such as photosynthetic efficiency and light adaptability. Similar studies have recently been conducted on sea-ice communities (Cota 1985, Palmisano et al. 1985, 1987). Many of these experiments attempted to simulate in situ productivity using small, compact incubators that use small sample volumes and measure ${ }^{14} \mathrm{C}$-uptake during short incubations (Lewis \& Smith 1983).

A number of investigations have documented the biological impacts of marginal ice zones (Alexander \& Niebauer 1981, Ainley et al. 1986, Smith \& Nelson 1986, Smith 1987). However, little is known about the

\footnotetext{
- Present address: Department of Marine Science, University of South Florida, St. Petersburg, Florida 33701, USA

- Addressee for correspondence
}

distributions and life strategies of polar communities during the reduced light conditions of winter. It has been hypothesized that polar phytoplankton reduce their metabolic rates during winter by forming overwintering stages which remain in the water column and resume growth when the light environment improves (Alexander 1980). Palmisano \& Sullivan (1983) simulated a seasonal irradiance change by exposing cells to a gradual decrease in light intensity followed by a gradual increase at low temperatures, and found that a large proportion of cells would remain viable for up to 6 mo. A second mechanism proposed for overwintering is incorporation into the ice-algal community, where cells would be maintained near the surface, exposed to light early in the growing season, and continually released into the water column (Garrison et al. 1983). The degree to which each mechanism or life strategy functions in nature, however, remains unclear.

This study was conducted to determine the distribution of phytoplankton during austral winter, the photosynthetic responses of the winter phytoplankton, and the contribution of primary productivity during the winter period to the annual carbon cycle of the Antarctic. Productivity during this period is generally assumed to be negligible (e.g. Smith \& Nelson 1986), despite a potentially favorable environment for phytoplankton 
growth. Favorable conditions include the availability of light at the surface near $60^{\circ} \mathrm{S}$ (up to $1.5 \mathrm{E} \mathrm{m}^{-2} \mathrm{~d}^{-1}$ on June 21; Campbell \& Aarup unpubl.), the introduction of meltwater at the ice edge which stratifies the water column, and the presence of enhanced concentrations of phytoplankton in the water column at some locations during winter (Dieckmann 1987).

\section{METHODS AND MATERIALS}

This study was part of the WINTERCRUISE II project conducted in and around the Bransfield Strait region of the Antarctic Peninsula from June 11 through July 10, 1987 on the RV 'Polar Duke' (Fig. 1). Stations depths ranged from $110 \mathrm{~m}$ at Stn 106 to $2400 \mathrm{~m}$ at Stn 56 , although depths were ca $700 \mathrm{~m}$ at most stations. Surface temperatures were determined at each station from bucket samples, and temperature profiles were obtained using expendable bathythermographs (XBTs). Continuous measurements of incident light were made using a Biospherical Instruments quantum meter (Model QSP-170) equipped with surface sensor (Model QSR-240 hemispeherical sensor), which was mounted on the upper decks of the research vessei where no shading occurred. A Biospherical Instruments underwater sensor (Model QSP-200 sensor) was used to determine light attenuation (and attenuation coefficients) within the water column, and sampling depths were based on light penetration. Phytoplankton were collected from the surface layers using 101 Niskin bottles. Chlorophyll a concentrations were determined by filtering known volumes through Gelman GF/F filters, grinding in $90 \%$ acetone and measuring the fluorescence before and after acidification on a Turner Designs fluorometer. The fluorometer was calibrated using commercially purified chlorophyll a (Sigma Chemical Co.).

Photosynthesis-irradiance relationships were measured with a method adapted from Lewis \& Smith (1983). Five $\mathrm{ml}$ samples were incubated with $50 \mu \mathrm{Ci}$ $\mathrm{H}^{14} \mathrm{CO}_{3}{ }^{-}$in an artificial light gradient for 2 to $4 \mathrm{~h}$. Incubations were terminated by the addition of $50 \mu \mathrm{l}$ $6 N \mathrm{HCl}$ to each sample. Following acid addition, all samples were placed in a Plexiglas container that allowed the samples to be bubbled with air for 1 to $2 \mathrm{~h}$ to remove ${ }^{14} \mathrm{CO}_{2}$. This procedure allowed both particulate and dissolved organic production to be measured together (Theodórsson \& Bjarnason 1975). Time-zero controls were treated in the same manner, except that the samples were acidified immediately following inoculation. Total added $\mathrm{H}^{14} \mathrm{CO}_{3}{ }^{-}$was determined by assaying the radioactivity in $500 \mu \mathrm{l}$ samples to which $50 \mu \mathrm{l}$ of $1 \mathrm{~N} \mathrm{KOH}$ had been added. Ten ml of Ecolume (ICN) were added to each sample and the radioactivity determined on a LKG scintillation counter. All counts were converted to disintegrations per minute by the external standard ratio method.

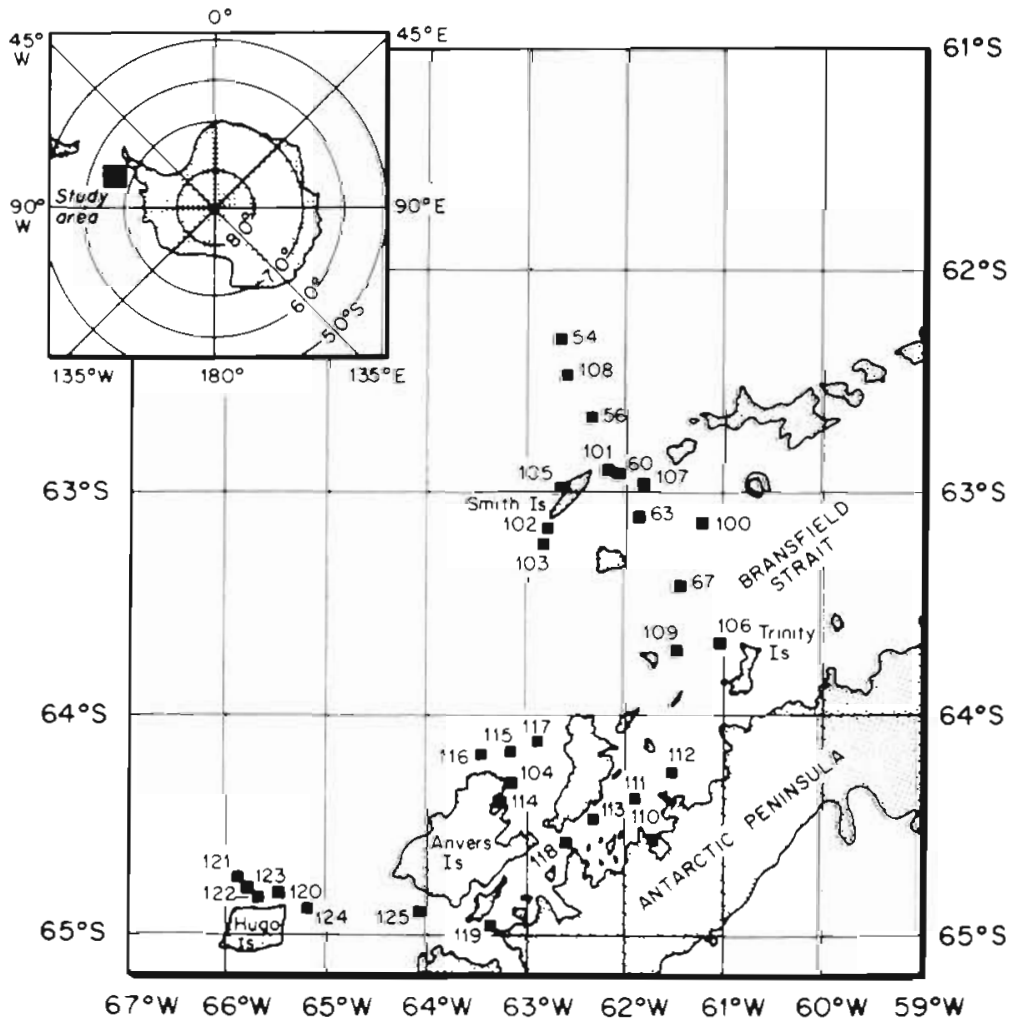

Fig. 1. Locations of stations occupied in the Bransfield Strait region 
The light-gradient incubators consisted of an aluminum sample block, a Plexiglas shield fitted with neutral density screens (Perforated Products, Brookline, MA, USA), and a main block that contained the light source. The sample block could hold up to 32 samples and was cooled to ambient temperatures (generally around $-1.5^{\circ} \mathrm{C}$ ) by a constant temperature circulator (Precision Inc.). The screens were attached to the Plexiglas shield and corresponded to light intensities ranging from 10 to $2000 \mu \mathrm{E} \mathrm{m}^{-2} \mathrm{~s}^{-1}$. The neutral density screens were calibrated using a Biospherical Instruments probe. Light measurements were taken at the bottom of each chamber in the incubator after each incubation was completed to assess any error associated with variation in the output of the lights. The light source within the main block was a General Electric Quartz Halogen $1500 \mathrm{~W}$ bulb. In addition to the light source, the main block contained 2 chambers for running seawater and a fan to assist in removing heat and maintaining the samples at ambient temperatures.

Photosynthesis-irradiance data were fitted to the model of Platt et al. (1980) using the equation

$$
P^{B}(I)=P_{s}^{B}\left(1-e^{-\alpha I / P_{s}^{B}}\right) \cdot e^{-\beta 1 / P_{s}^{B}}
$$

where $\mathrm{P}^{\mathrm{B}}(\mathrm{I})=$ photosynthetic rate $\left(\mathrm{mg} \mathrm{C}(\mathrm{mg} \mathrm{chl})^{-1} \mathrm{~h}^{-1}\right)$ at irradiance $\mathrm{I}\left(\mu \mathrm{E} \mathrm{m}^{-2} \mathrm{~s}^{-1}\right) ; \mathrm{P}_{\mathrm{s}}^{\mathrm{B}}=$ light-saturated photosynthetic rate $\left(\mathrm{mg} \mathrm{C}(\mathrm{mg} \mathrm{chl})^{-1} \mathrm{~h}^{-1}\right)$ in the absence of photoinhibition; $\alpha=$ initial slope of the P-I curve ( $m g \mathrm{C}$ $\left.(\mathrm{mg} \mathrm{chl})^{-1} \mathrm{~h}^{-1}\left(\mu \mathrm{E} \mathrm{m} \mathrm{m}^{-2} \mathrm{~s}^{-1}\right)^{-1}\right) ; \beta=$ an index of photoinhibition $\left(\mathrm{mgC}(\mathrm{mg} \mathrm{chl})^{-1} \mathrm{~h}^{-1}\left(\mu \mathrm{E} \mathrm{m} \mathrm{m}^{-2} \mathrm{~s}^{-1}\right)^{-1}\right)$. The susceptibility to photoinhibition was determined from the equation

$$
I_{b}=P_{s}^{B} / \beta
$$

where $I_{b}=$ the light intensity at which the extrapolated curve intersects the axis (Platt et al. 1980). In addition, the maximum photosynthetic rate attained $\left(\mathrm{P}_{\mathrm{m}}^{\mathrm{B}}\right)$ was calculated using the formula

$$
\mathrm{P}_{\mathrm{m}}^{\mathrm{B}}=\mathrm{P}_{\mathrm{s}}^{\mathrm{B}}[\alpha /(\alpha+\beta)] \cdot[\beta /(\alpha+\beta)]^{\beta / \alpha}
$$

and the irradiance at which photosynthesis is maximal $\left(\mathrm{I}_{\mathrm{m}}\right)$ calculated from the equation

$$
\mathrm{I}_{\mathrm{m}}=\mathrm{p}_{\mathrm{s}}^{\mathrm{B}} / \alpha \quad \ln [(\alpha+\beta) / \beta]
$$

The index of photoadaptation $\left(\mathrm{I}_{\mathrm{k}}\right)$ was estimated from

$$
\mathrm{I}_{\mathrm{k}}=\mathrm{P}_{\mathrm{m}}^{\mathrm{B}} / \alpha
$$

Photosynthetic parameters were derived from the objective curve-fitting procedures of Zimmerman et al. (1987) for each sample set corresponding to a particular depth.

Simulated in situ primary productivity measurements were conducted in concert with the P-I determinations. Samples $(280 \mathrm{ml})$ were collected, inoculated with ca $80 \mu \mathrm{Ci} \mathrm{H}^{14} \mathrm{CO}_{3}{ }^{-}$, incubated for $24 \mathrm{~h}$ on-deck, and fil- tered onto Millipore HA filters ( $0.45 \mu \mathrm{m}$ pore size) Samples were dried at $60^{\circ} \mathrm{C}$, after which $10 \mathrm{ml}$ of scintillation fluor were added and the samples counted as described above. A complete analytical description is given by Wilson et al. (1986).

\section{RESULTS}

\section{Vertical distribution of physical and biological parameters}

Solar radiation was extremely low as a result of the low solar angle and shortened daylength. The photoperiod averaged $6.1 \mathrm{~h}( \pm 0.28, n=28)$ and remained nearly constant during the sampling period (Fig. 2).

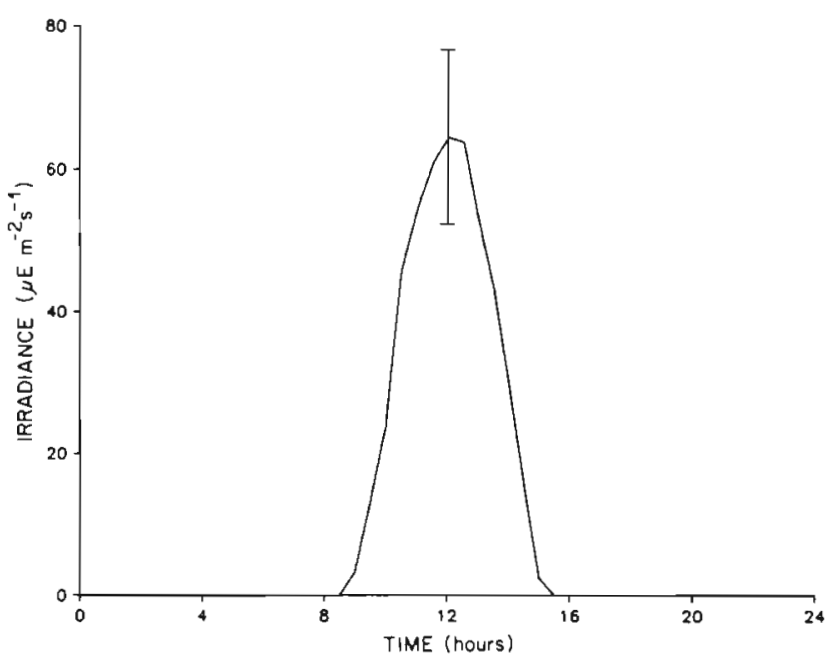

Fig. 2. Mean photoperiod during the cruise. Bar around maximal irradiance indicates standard deviation for sampling period

Mean integrated daily irradiance was $0.795 \mathrm{E} \mathrm{m}^{-2}$ $( \pm 0.263, n=27)$ and varied with cloud cover and precipitation. Percent transmittance of light across the ocean's surface was $31.9 \%$ (albedo $=\mathrm{ca} 0.70$ ), and the depth to which $0.1 \mu \mathrm{E} \mathrm{m}^{-2} \mathrm{~s}^{-1}$ penetrated in open water locations occurred at ca $40 \mathrm{~m}$, which corresponded to an attenuation coefficient of $0.15 \mathrm{~m}^{-1}$.

Expendable bathythermograph profiles indicated that a thermocline occurred at 75 to $100 \mathrm{~m}$ in the western (and shallower) portion of the Bransfield Strait but was absent in the deeper, open ocean portions of the study area near the opening to the Weddell Sea (Fig. 3a). Water temperatures of surface waters for open ocean stations and areas within the Bransfield Strait averaged $-1.58^{\circ} \mathrm{C}( \pm 0.25, n=20)$. Lack of an operable CTD prevented collection of continuous salinity and density profiles needed to determine the depth and strength of any pycnocline. The 
degree of ice-coverage varied from station to station, ranging from zero percent coverage up to total ice cover.
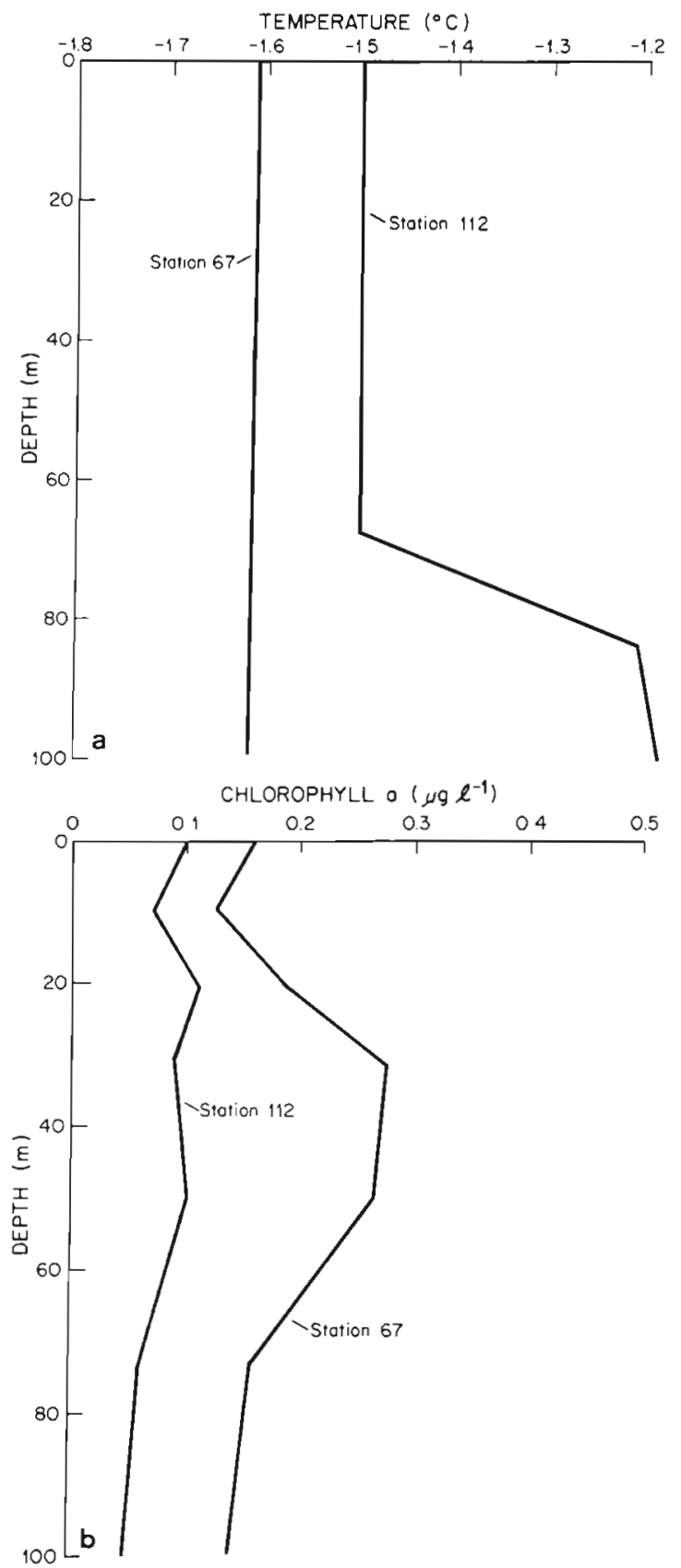

Fig. 3. Representative profiles (Stns 67 and 112) of (a) temperature and (b) chlorophyll a

Nutrient data were not collected during the cruise, but nutrients are rarely reduced at any season to levels considered to be limiting to phytoplankton growth (Sakshaug \& Holm-Hansen 1984). Chlorophyll a concentrations averaged $0.183 \mu \mathrm{g} \mathrm{l}^{-1}( \pm 0.09)$ at the surface, and at $50 \mathrm{~m}$ averaged $0.175 \mu \mathrm{gl} \mathrm{l}^{-1}( \pm 0.14)$, slightly less than those at the surface but not significantly different. In general, the distribution of chlorophyll a was controlled by the depth of mixing, being uniform in the surface mixed layer (Fig. 3b). Nanoplankton and small diatoms were the numerically dominant members of the algal assemblages, but the colonial form of the prymnesiophyte Phaeocystis pouchettii was not observed.

\section{Photosynthesis-irradiance determinations}

Few spatial variations in photosynthesis-irradiance parameters were found within the Bransfield Strait region (Table 1). Photosynthetic efficiencies $(\alpha)$ averaged $0.021 \mathrm{mg} \mathrm{C}(\mathrm{mg} \mathrm{chl})^{-1} \mathrm{~h}^{-1}\left[\mu \mathrm{E} \mathrm{m}^{-2} \mathrm{~s}^{-1}\right]^{-1}( \pm 0.01)$ for surface waters and $0.031 \mathrm{mg} C(\mathrm{mg} \mathrm{chl})^{-1} \mathrm{~h}^{-1}[\mu \mathrm{E}$ $\left.\mathrm{m}^{-2} \mathrm{~s}^{-1}\right]^{-1}( \pm 0.02)$ for $50 \mathrm{~m}$. Photosynthetic efficiencies varied slightly among stations but were similar within each station at the surface and $50 \mathrm{~m}$. Maximum assimilation numbers $\left(\mathrm{P}_{\mathrm{m}}^{\mathrm{B}}\right)$ were found to average $1.19 \mathrm{mg} \mathrm{C}(\mathrm{mg} \mathrm{chl})^{-1} \mathrm{~h}^{-1}( \pm 0.58)$ in surface waters and $1.10 \mathrm{mg} C(\mathrm{mg} \mathrm{chl})^{-1} \mathrm{~h}^{-1}( \pm 0.06)$ at $50 \mathrm{~m}$. The values for $I_{k}$, an index of photoadaptation, were higher for surface samples than for $50 \mathrm{~m}$ populations, and averaged 60.2 and $39.7 \mu \mathrm{E} \mathrm{m}^{-2} \mathrm{~s}^{-1}$, respectively (Table 1).

Photoinhibition occurred in both surface and $50 \mathrm{~m}$ populations and began at ca $300 \mu \mathrm{E} \mathrm{m}^{-2} \mathrm{~s}^{-1}$ (Table 1). The $\alpha$ values were approximately the same at the surface and $50 \mathrm{~m}$, averaging $0.001 \mathrm{mg} \mathrm{C}(\mathrm{mg} \mathrm{chl})^{-1} \mathrm{~h}^{-1}$

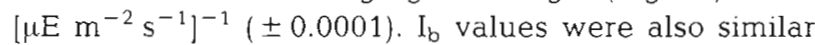
between the 2 depths within a station, but were highly variable among all stations.

Photosynthesis-irradiance relationships did not exhibit large spatial variations within the Bransfield Strait. For example, P-I curves from Stn 108, an open water station, indicated that there was no difference between 0 and $50 \mathrm{~m}$ populations in $\alpha, \beta$ or $\mathrm{P}_{\mathrm{m}}^{\mathcal{B}}$ (Fig. 4). Similarly, at Stn 112, within the Bransfield Strait, no difference was observed in photosynthetic parameters at the surface and $50 \mathrm{~m}$, although photosynthetic efficiencies were slightly higher at $50 \mathrm{~m}$ than for surface assemblages (Fig. 5). Stn 110 was located in a semi-enclosed bay, and the observed $P_{m}^{B}$ and $\beta$ values from 0 and $50 \mathrm{~m}$ were markedly different (Fig. 6). At this station the 2 assemblages had similar $\alpha$ values, but $\mathrm{P}_{\mathrm{m}}^{\mathrm{B}}$ values at $50 \mathrm{~m}$ were twice those of surface populations and $\beta$ values were 5 times as high. $\mathrm{P}_{\mathrm{m}}^{\mathrm{B}}$ values were markedly lower at Stn 110 than at other stations, which suggests that resuspension of phytoplankton which had settled to sediments earlier may have been occurring (Krebs 1983, Palmisano et al. 1985).

Primary productivity was estimated by combining information on daily incident irradiance, measure- 
ments of water column attenuation coefficients and chlorophyll concentrations, and a quantitative description of the photosynthesis-irradiance responses (Platt \& Gallegos 1980). Two compensation intensities were used in the calculations (1.0 and $0.1 \mu \mathrm{E} \mathrm{m}^{-2} \mathrm{~s}^{-1}$ ) because Antarctic phytoplankton have previously been reported to photosynthesize at extremely low light intensities (El-Sayed et al. 1983). However, nocturnal respiration was not included in the productivity calculations. Computed daily productivity was low, ranging from 0.4 to $6.9 \mathrm{mg} \mathrm{C} \mathrm{m} \mathrm{C} \mathrm{d}^{-1}$ and 0.4 to $7.0 \mathrm{mg} \mathrm{C}$ $\mathrm{m}^{-2} \mathrm{~d}^{-1}$, depending on the compensation intensity used (Table 2). Parallel measurements of ${ }^{14} \mathrm{C}$-uptake from simulated in situ experiments ranged from 2.7 to $10.8 \mathrm{mg} \mathrm{C} \mathrm{m}^{-2} \mathrm{~d}^{-1}$ and confirmed the low but positive rates of primary productivity (Table 2 ). Measured productivity was greater than that of the values calculated from photosynthesis-irradiance relationships, but no systematic difference between the 2 estimates was observed, with some simulated in situ values being less than the calculated values and some being larger (Table 2).

Table 1. Summary of photosynthetic-irradiance parameters for all stations. Standard deviations are in parentheses. Units $-P_{s}^{B}, P_{m}^{B}$ : $m g C(m g \text { chl })^{-1} h^{-1} ; \alpha, \beta$ : mg $C(m g c h l)^{-1} h^{-1}\left[\mu \mathrm{E} \mathrm{m}^{-2} s^{-1}\right]^{-1} ; I_{m}, I_{k}, I_{b}: \mu E m^{-2} s^{-1}$

\begin{tabular}{|c|c|c|c|c|c|c|c|c|}
\hline Station & $\begin{array}{l}\text { Depth } \\
\text { (m) }\end{array}$ & $P_{s}^{B}$ & $\alpha$ & $\beta$ & $P_{m}^{B}$ & $I_{m}$ & $\mathrm{I}_{\mathrm{k}}$ & $\mathrm{I}_{\mathrm{b}}$ \\
\hline 100 & 0 & $\begin{array}{l}2.64 \\
(0.4)\end{array}$ & $\begin{array}{l}0.042 \\
(0.01)\end{array}$ & $\begin{array}{l}0.627 \\
(0.001)\end{array}$ & 2.44 & 267 & 59 & 4201 \\
\hline 101 & 0 & $\begin{array}{l}1.09 \\
(0.3)\end{array}$ & $\begin{array}{l}0.012 \\
(0.01)\end{array}$ & $\begin{array}{l}1.113 \\
(0.001)\end{array}$ & 0.80 & 218 & 64 & 969 \\
\hline 102 & 0 & $\begin{array}{l}1.60 \\
(0.2)\end{array}$ & $\begin{array}{l}0.020 \\
(0.01)\end{array}$ & $\begin{array}{l}1.502 \\
(0.0004)\end{array}$ & 1.23 & 207 & 59 & 1066 \\
\hline 103 & 0 & $\begin{array}{l}1.12 \\
(0.1)\end{array}$ & $\begin{array}{l}0.020 \\
(0.01)\end{array}$ & $\begin{array}{l}8.522 \\
(0.0002)\end{array}$ & 0.93 & 181 & 48 & 1313 \\
\hline 103 & 50 & $\begin{array}{l}0.53 \\
(0.03)\end{array}$ & $\begin{array}{l}0.030 \\
\{0.002\}\end{array}$ & $\begin{array}{l}0.391 \\
(0.0001)\end{array}$ & 0.46 & 222 & 42 & 1364 \\
\hline 104 & 0 & $\begin{array}{l}0.88 \\
(0.1)\end{array}$ & $\begin{array}{l}0.018 \\
\{0.01\}\end{array}$ & $\begin{array}{l}0.713 \\
(0.0001)\end{array}$ & 0.74 & 158 & 41 & 1232 \\
\hline 105 & 0 & $\begin{array}{l}1.00 \\
(0.1)\end{array}$ & $\begin{array}{l}0.020 \\
(0.01)\end{array}$ & $\begin{array}{l}0.563 \\
(0.0001)\end{array}$ & 0.88 & 185 & 46 & 1782 \\
\hline 106 & 0 & $\begin{array}{l}3.68 \\
(2.2)\end{array}$ & $\begin{array}{l}0.011 \\
(0.002)\end{array}$ & $\begin{array}{l}2.885 \\
(0.003)\end{array}$ & 1.92 & 530 & 177 & 1277 \\
\hline 106 & 50 & $\begin{array}{l}1.20 \\
(0.1)\end{array}$ & $\begin{array}{l}0.026 \\
(0.01)\end{array}$ & $\begin{array}{l}1.984 \\
(0.0001)\end{array}$ & 1.14 & 222 & 44 & 5519 \\
\hline 107 & 0 & $\begin{array}{l}1.41 \\
(0.1)\end{array}$ & $\begin{array}{l}0.030 \\
(0.01)\end{array}$ & $\begin{array}{l}0.920 \\
(0.0002)\end{array}$ & 1.22 & 169 & 42 & 1528 \\
\hline 108 & 0 & $\begin{array}{l}2.40 \\
(0.2)\end{array}$ & $\begin{array}{l}0.030 \\
(0.004)\end{array}$ & $\begin{array}{l}1.937 \\
(0.0004)\end{array}$ & 1.90 & 223 & 62 & 1241 \\
\hline 108 & 50 & $\begin{array}{l}2.50 \\
(0.2)\end{array}$ & $\begin{array}{l}0.044 \\
(0.01)\end{array}$ & $\begin{array}{l}1.984 \\
(0.001)\end{array}$ & 2.08 & 180 & 48 & 1262 \\
\hline 109 & 0 & $\begin{array}{l}1.32 \\
(0.1)\end{array}$ & $\begin{array}{l}0.030 \\
(0.01)\end{array}$ & $\begin{array}{l}6.199 \\
(0.0002)\end{array}$ & 1.19 & 170 & 39 & 2122 \\
\hline 110 & 0 & $\begin{array}{l}0.23 \\
(0.3)\end{array}$ & $\begin{array}{l}0.006 \\
(0.004)\end{array}$ & $\begin{array}{l}0.063 \\
(0.0001)\end{array}$ & 0.22 & 179 & 37 & 3722 \\
\hline 110 & 50 & $\begin{array}{l}0.54 \\
(0.3)\end{array}$ & $\begin{array}{l}0.010 \\
(0.002)\end{array}$ & $\begin{array}{l}0.506 \\
(0.0001)\end{array}$ & 0.45 & 162 & 44 & 1077 \\
\hline 111 & 0 & $\begin{array}{l}1.14 \\
(0.1)\end{array}$ & $\begin{array}{l}0.030 \\
(0.01)\end{array}$ & $\begin{array}{l}0.689 \\
(0.0002)\end{array}$ & 1.01 & 163 & 40 & 1658 \\
\hline 112 & 0 & $\begin{array}{l}1.43 \\
(0.2)\end{array}$ & $\begin{array}{l}0.015 \\
(0.004)\end{array}$ & $\begin{array}{l}1.504 \\
(0.0005)\end{array}$ & 1.02 & 229 & 68 & 950 \\
\hline 112 & 50 & $\begin{array}{l}1.30 \\
(0.1)\end{array}$ & $\begin{array}{l}0.066 \\
(0.02)\end{array}$ & $\begin{array}{l}0.930 \\
(0.0002)\end{array}$ & 1.24 & 215 & 41 & 7001 \\
\hline 116 & 50 & $\begin{array}{l}1.12 \\
(0.1)\end{array}$ & $\begin{array}{l}0.031 \\
(0.01)\end{array}$ & $\begin{array}{l}0.185 \\
(0.0002)\end{array}$ & 1.25 & 215 & 41 & 7001 \\
\hline 116 & 100 & $\begin{array}{l}1.30 \\
(0.1)\end{array}$ & $\begin{array}{l}0.032 \\
(0.01)\end{array}$ & $\begin{array}{l}0.011 \\
(0.0001)\end{array}$ & 1.11 & 276 & 34 & 103319 \\
\hline Average & $(0 \mathrm{~m})$ & $\begin{array}{l}1.53 \\
(0.9)\end{array}$ & $\begin{array}{l}0.021 \\
(0.01)\end{array}$ & $\begin{array}{l}1.077 \\
(0.73)\end{array}$ & $\begin{array}{l}1.19 \\
(0.6)\end{array}$ & $\begin{array}{c}221 \\
(102)\end{array}$ & $\begin{array}{r}60 \\
(37)\end{array}$ & $\begin{array}{c}1774 \\
(1076)\end{array}$ \\
\hline Average & $(50 \mathrm{~m})$ & $\begin{array}{l}1.24 \\
(0.7)\end{array}$ & $\begin{array}{l}0.031 \\
(0.02)\end{array}$ & $\begin{array}{l}0.702 \\
(0.70)\end{array}$ & $\begin{array}{l}1.10 \\
(0.6)\end{array}$ & $\begin{array}{l}172 \\
(49)\end{array}$ & $\begin{array}{r}40 \\
(11)\end{array}$ & $\begin{array}{c}2944 \\
(2613)\end{array}$ \\
\hline
\end{tabular}




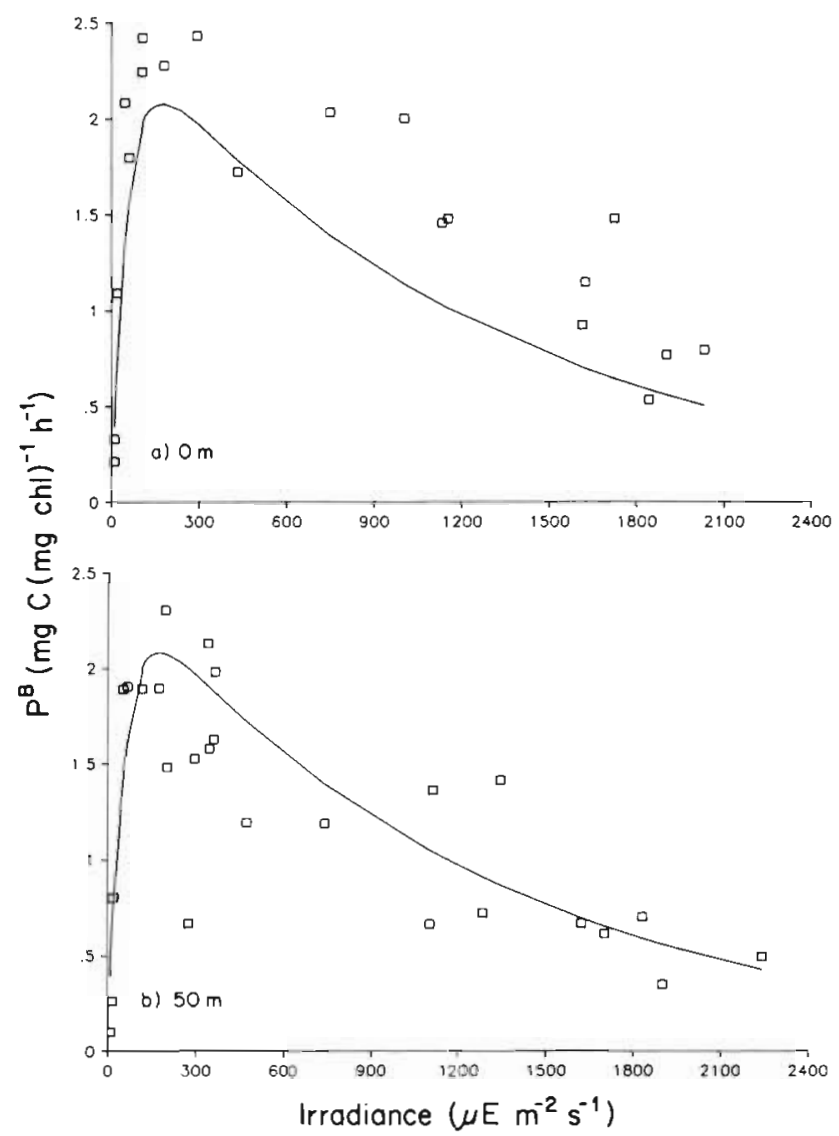

Fig. 4. Photosynthesis as a function of irradiance at Stn 108 at (a) 0 and (b) $50 \mathrm{~m}$. Stn 108 was located in open water (total depth $560 \mathrm{~m}$ )

\section{DISCUSSION}

Our results show that during the winter season in the Bransfield Strait low standing stocks of phytoplankton occurred and that they were adapted to low irradiances. Previous work on photosynthesis-irradiance relationships within the Bransfield Strait had been conducted in the summer by Tilzer et al. $(1985,1986)$. The photosynthesis-irradiance parameters we observed were slightly different from those reported previously. For example, our photosynthetic efficiencies $(\alpha)$ ranged from 0.01 to $0.06 \mathrm{mg} \mathrm{C}(\mathrm{mg} \mathrm{chl})^{-1} \mathrm{~h}^{-1}\left[\mu \mathrm{E} \mathrm{m} \mathrm{m}^{-2} \mathrm{~s}^{-1}\right]^{-1}$, whereas Tilzer et al. $(1985,1986)$ found $\alpha$ values to range from 0.001 to $0.011 \mathrm{mg} \mathrm{C}\left(\mathrm{mg} \mathrm{chl}^{-1} \mathrm{~h}^{-1}\left[\mu \mathrm{E} \mathrm{m}{ }^{-2}\right.\right.$ $\mathrm{s}^{-1} \mathrm{j}^{-1}$. Values similar to ours (ca $0.01 \mathrm{mg} \mathrm{C}(\mathrm{mg} \mathrm{chl})^{-1}$ $\mathrm{h}^{-1}\left[\mu \mathrm{E} \mathrm{m} \mathrm{m}^{-2} \mathrm{~s}^{-1}\right]^{-1}$ ) have been found in the Arctic (see Platt et al. 1982). The greater efficiencies which we found during winter indicate that the phytoplankton assemblage was adapted to low light conditions (Prézelin 1981), a conclusion also supported by the lower light intensities required to saturate photosynthesis $\left(\mathrm{I}_{\mathrm{k}}\right.$ values of ca $45 \mu \mathrm{E} \mathrm{m} \mathrm{m}^{-2} \mathrm{~s}^{-1}$; Table 1). For comparison,
Tilzer et al. $(1985,1986)$ found $I_{k}$ values of near $100 \mu E$ $\mathrm{m}^{-2} \mathrm{~s}^{-1}$ during their summer study. Our $\mathrm{I}_{\mathrm{k}}$ estimates are similar to ice algal populations which grow in a constant, low light environment (Cota 1985, Palmisano et al. 1985, 1987).

The $\mathrm{P}_{\mathrm{m}}^{\mathrm{B}}$ values we found were slightly higher than those observed during the summer (Tilzer et al. 1985, 1986). Winter maximum assimilation numbers ranged from 0.7 to $2.4 \mathrm{mg} \mathrm{C}(\mathrm{mg} \mathrm{chl})^{-1} \mathrm{~h}^{-1}$, compared to summer values which ranged from 0.5 to $1.2 \mathrm{mg} \mathrm{C}$ (mg chl $)^{-1} \mathrm{~h}^{-1}$. Values for Arctic phytoplankton also overlapped this range, and the mean value was $1.21 \mathrm{mg} \mathrm{C}$ $(\mathrm{mg} \mathrm{chl})^{-1} \mathrm{~h}^{-1}$ (Harrison \& Platt 1986).

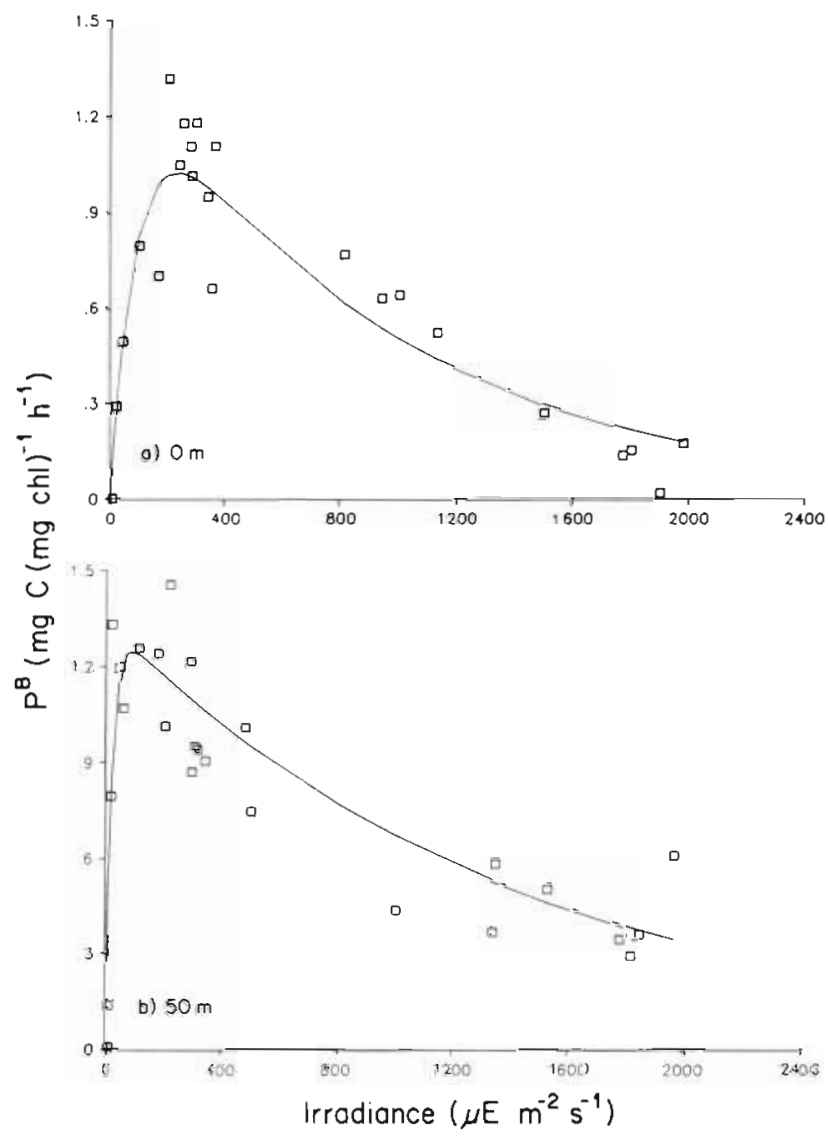

Fig 5. Photosynthesis as a function of irradiance at Stn 112 at (a) 0 and (b) $50 \mathrm{~m}$. Stn 112 was within the Bransfield Strait (total depth $150 \mathrm{~m}$ )

The absence of apparent differences between P-I curves and related parameters among depths suggest that the populations within the water column were biologically homogeneous and that the rate of adaptation was less than that of turbulent mixing. Because of the unfortunate lack of continuous salinity (and therefore density) measurements during the cruise, we cannot adequately describe the depth of the mixed layer and describe the approximate times of vertical mixing 
as has been done previously in temperate regions (Gallegos et al. 1983). However, based on the uniform temperature and particulate matter distributions as well as the similarity in photosynthesis-irradiance responses of samples from within the upper $100 \mathrm{~m}$, we feel that mixing rates were fast enough to preclude any photoadaptation within the upper layer of the water column.

Daily production rates, estimated either from P-I relationships or simulated in situ measurements, during the Antarctic winter were low and ranged up to $7.03 \mathrm{mg} \mathrm{C}$ $\mathrm{m}^{-2} \mathrm{~d}^{-1}$. These values are much lower (more than 2 orders of magnitude) than spring and summer values

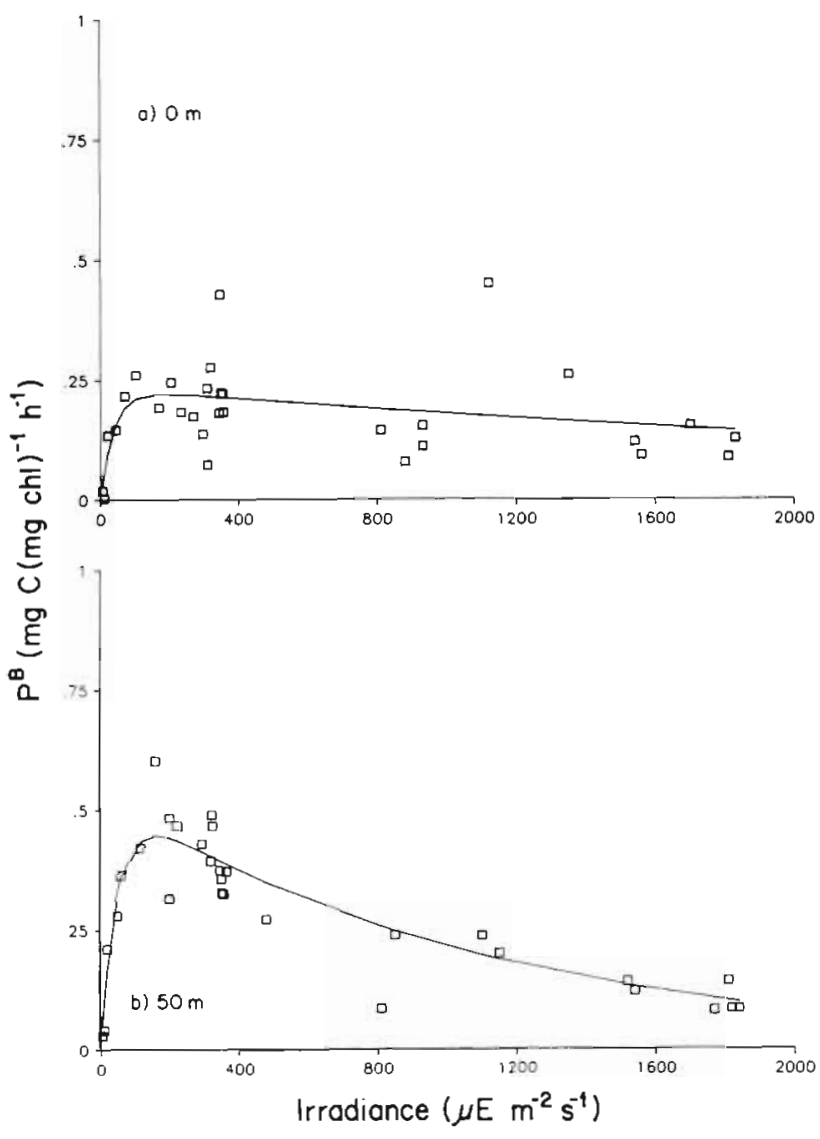

Fig. 6. Photosynthesis as a function of irradiance at Stn 110 at (a) 0 and (b) $50 \mathrm{~m}$. Stn 110 was within an embayment in Bransfield Strait (total depth $103 \mathrm{~m}$ )

from the region, and despite the long periods of low light over wide areas of the Antarctic, the productivity integrated throughout the entire winter will still be a minor contribution to the carbon cycle of the region. To illustrate the quantitative contribution of winter phytoplankton production, if the productivity was $7 \mathrm{mg} \mathrm{C}$ $\mathrm{m}^{-2} \mathrm{~d}^{-1}$ for $180 \mathrm{~d}$ (the approximate period assumed to have zero productivity by Smith \& Nelson 1986), the total production for the 6 mo period would still be only slightly over $1 \mathrm{~g} \mathrm{C}^{-2}$, which is less than each day's production within an ice-edge bloom (Wilson et al. 1986). Other estimates of annual and interannual productivity of the Antarctic and the southern ocean marginal ice zone (Smith \& Nelson 1986, Smith et al. 1988) have not included this production, but the error introduced by not including the winter production will be small. Kottmeier \& Sullivan (1987) measured productivity at 4 stations in August and September in the same region and found productivity to range from undetectable to $1101 \mathrm{mg} \mathrm{C} \mathrm{m}^{-2} \mathrm{~d}^{-1}$. It should be pointed out that the 2 other stations had productivities of 11 and $40 \mathrm{mg}$ $\mathrm{C} \mathrm{m}^{-2} \mathrm{~d}^{-1}$, so that the one value of over $1 \mathrm{~g} \mathrm{C} \mathrm{m}^{-2} \mathrm{~d}^{-1}$ is extreme. When the assimilation number is calculated for this station (>13 $\mathrm{mg} \mathrm{C}(\mathrm{mg} \mathrm{chl})^{-1} \mathrm{~h}^{-1}$ ), it is clear that this estimate is in error, since the $\mathrm{P}_{\mathrm{m}}^{\mathrm{B}}$ value is greater than that theoretically attainable at these temperatures (Li 1980).

Table 2. Primary productivity as estimated by simulated in situ carbon uptake measurements and photosynthesis-irradiance relationships. Photosynthetic parameters used were the means of 0 and $50 \mathrm{~m}$ unless biological stratification was noted. Two compensation intensities were used: (A) 1.0 and (B) 0.1 $\mu \mathrm{E} \mathrm{m}^{-2} \mathrm{~s}^{-1}$

\begin{tabular}{|c|c|c|c|}
\hline \multirow[t]{2}{*}{ Station } & \multirow{2}{*}{$\begin{array}{c}\text { In situ } \\
\text { productivity } \\
\left(\mathrm{mgC} \mathrm{Cm}^{-2} \mathrm{~d}^{-1}\right)\end{array}$} & \multicolumn{2}{|c|}{$\begin{array}{l}\text { Calculated productivity } \\
\left(\mathrm{mg} \mathrm{C} \mathrm{m}^{-2} \mathrm{~d}^{-1}\right)\end{array}$} \\
\hline & & A & B \\
\hline 100 & 4.87 & 3.93 & 4.02 \\
\hline 101 & 4.01 & 1.74 & 1.75 \\
\hline 102 & ND & 4.01 & 4.09 \\
\hline 103 & 6.18 & 2.74 & 2.79 \\
\hline 104 & 10.8 & 2.66 & 2.71 \\
\hline 105 & ND & 2.15 & 2.19 \\
\hline 106 & 2.99 & 0.39 & 0.40 \\
\hline 107 & ND & 2.50 & 2.54 \\
\hline 108 & 6.11 & 6.90 & 7.03 \\
\hline 109 & ND & 1.42 & 1.44 \\
\hline 110 & 6.66 & 0.42 & 0.43 \\
\hline 111 & ND & 0.73 & 0.74 \\
\hline 112 & 3.40 & 0.61 & 0.62 \\
\hline 116 & 2.74 & 2.34 & 2.39 \\
\hline \multicolumn{4}{|c|}{ ND: no data } \\
\hline
\end{tabular}

Because respiration rates were not included in our calculated daily production rates, the productivity calculated from P-I experiments is an overestimate. Respiratory rates are highly variable in nature, although a photosynthesis:respiration ratio of 10 is generally accepted as an average value (Burris 1980). However, there is evidence that the low temperatures (less than $0^{\circ} \mathrm{C}$ ) at which polar phytoplankton grow cause respiratory rates to decrease more than photosynthetic rates (Neori \& Holm-Hansen 1982, Tilzer \& Dubinsky 1987). Therefore, respiratory demands of 
polar phytoplankton may be only a small percentage of photosynthetic rates. Although the exclusion of respiration from the calculated productivity values will cause an overestimate, the error in polar waters is probably slight.

The value of the compensation point also is important in the calculation of productivity. Values for compensation intensities for polar phytoplankton and ice algae range from 1.4 to less than $0.2 \mu \mathrm{E} \mathrm{m}^{-2} \mathrm{~s}^{-1}$ (Platt et al. 1982, Cota 1985). These values are derived from estimates of respiration rates from P-I curves, and there is considerable variation associated with such estimates (Gallegos et al. 1983); therefore, the use of 2 assumed compensation intensities should result in a reasonable estimate of productivity during this period. El-Sayed et al. (1983) found considerable amounts of productivity below the $1 \%$ light depth, and concluded that Antarctic phytoplankton are adapted to low light conditions and are capable of net photosynthesis at great depth. Other investigations (Bodungen et al. 1986, Wilson et al. 1986, Weber \& El-Sayed 1987), however, did not find significant carbon fixation below the $0.1 \%$ light level, so that the importance of primary productivity at low light levels (less than $1 \%$ of incident irradiance) is probably negligible.

Recently it has been reported that phytoplankton from McMurdo Sound in the Ross Sea exhibit distinct but seasonally variable patterns in photosynthetic parameters ( $\alpha$ and $\beta$ values; Rivkin \& Putt 1987). It was found that maximum photosynthetic rates occurred near local noon in the early spring, and that a shift in the time of the maximum occurred throughout the season, so that by late spring the maximum occurred at midnight. Furthermore, it was suggested that this effect might cause significant underestimates of primary productivity if the carbon uptake measurements were of short duration and consistently centered around noon. Our samples for productivity were taken as we came on station and with no set initial time of sampling, so that any diel periodicity in photosynthetic parameters would be included in the scatter. The season sampled should also have exhibited near maximum photosynthetic capacity during the daylight hours, when the sampling for ${ }^{14} \mathrm{C}$-uptake measurements occurred. However, all of our values were based on $24 \mathrm{~h}$ incubations and hence any diel rhythm would not impact the daily uptake rates.

A great deal of work has been done in the Bransfield Strait region in the past $30 \mathrm{yr}$, which in large part can be attributed to the large standing stocks of krill and higher trophic levels that have often been observed (Everson 1977). Studies of phytoplankton biomass and productivity have also been frequently conducted in the area (e.g. Hart 1934, Burkholder \& Mandelli 1965, El-Sayed 1967, Bodungen et al. 1986, Kottmeier \&
Sullivan 1987), but none of these have addressed the standing stocks of phytoplankton and the photosynthetic rates during the period of minimal solar irradiance. Chlorophyll a concentrations up to $30 \mathrm{\mu g} \mathrm{l}^{-1}$ have previously been found in the Gerlache Strait in late summer (Burkholder \& Mandelli 1965, El-Sayed 1967), and given the season in which this study was completed, it is not surprising that these values were nearly 2 orders of magnitude greater than ours. Our results show that during austral winter conditions the Antarctic is a region of extremely low productivity, with the resident phytoplankton populations adapted to very low light conditions. The contribution of organic matter production to the food web by phytoplankton at this time is minor, although the contribution by ice algae during these periods may be greater. The extent to which winter productivity supports grazing organisms such as krill Euphausia superba during the nonbloom periods is uncertain, but productivity by ice algae and phytoplankton probably provide an additional energy source and decrease the dependence on previously stored energy reserves. The adaptations of the phytoplankton to low irradiances also allow them to remain in an active state and hence are available as inocula to initiate growth in the water column early in the austral spring. Thus, despite the low productivity of Antarctic phytoplankton during austral winter, the ecological importance of over-wintering phytoplankton may be greater than their standing stocks indicate.

Acknowledgements. We thank Dr G. Cota for his constructive review of the manuscript in its various forms, and Dr P. Boyce and Ms D. Vogelin for field assistance. Dr C. Sullivan provided the incident irradiance data. This research is a contribution to AMERIEZ (Antarctic Marine Ecosystems Research at the Ice Edge Zone) and was supported by National Science Foundation grant DPP-8420213. Ship-time was kindly provided by Dr L. Quetin and supported by NSF grant DPP-8518872

\section{LITERATURE CITED}

Ainley, D. G., Fraser, W. R., Sullivan, C. W., Torres, J. J. Hopkins, T L., Smith, W. O. (1986). Antarctic mesopelagic micronekton: evidence from seabirds that pack ice affects community structure. Science 232: 847-849

Alexander, V (1980). Interrelationships between seasonal sea ice and biological regimes. Cold Reg. Sci. Tech. 2: 157-178

Alexander, V., Niebauer, H. J. (1981). Oceanography of the Bering Sea ice-edge zone in spring. Limnol. Oceanogr. 26: $1111-1125$

Bodungen, B. von, Smetacek, V. S., Tilzer, M. M., Zeitzschel, B. (1986). Primary production and sedimentation during spring in the Antarctic Peninsula region. Deep Sea Res. 33: 177-194

Burkholder, P. R., Mandelli, E. F (1965). Carbon assimilation of marine phytoplankton in the Antarctic. Proc. natn. Acad. Sci. U.S.A. $54: 437-444$

Burris, J. E. (1980). Respiration and photorespiration in marine algae. In: Falkowski, P. G. (ed.) Primary productivity in the sea. Plenum Press, New York, p. 411-432 
Cota, G. F. (1985). Photoadaptation of high Arctic ice algae Nature, Lond. 315: 219-222

Dieckmann, G. (1987). High phytoplankton biomass at the advancing ice edge in the Northern Weddell Sea during winter EOS 68: 1765 (A.bstract)

El-Sayed, S. Z. (1967). On the productivity of the Southwest Atlantic Ocean and the waters of the Antarctic Peninsula. In: Schmitt, W., Llano, G. (eds.) Biology of the Antarctic seas, Vol. 2. American Geophysical Union, Washington, D.C., p. $5-47$

El-Sayed, S. Z., Biggs, D. C., Holm-Hansen, O. (1983). Phytoplankton standing crop, primary productivity, and nearsurface nitrogenous fields in the Ross Sea, Antarctica. Deep Sea Res. 30: 871-886

Everson, I. (1977). The living resources of the southern ocean. FAO, Rome

Gallegos, C. L., Platt., T., Harrison, W. G., Irwin, B. (1983). Photosynthetic parameters of arctic marine phytoplankton: vertical variations and time scales of adaptation. Limnol. Oceanogr. 28: 698-708

Garrison, D. L., Ackley, S. F., Buck, K. R. (1983). A physical mechanism for establishing algal populations in frazil ice. Nature, Lond. 306: 363-365

Harrison, W G., Platt, T (1986). Photosynthesis-irradiance relationships in polar and temperate phytoplankton populations. Polar Biol. 5: 153-164

Harrison, W. G., Platt, T., Lewis, M. R. (1985). The utility of light-saturation models for estimating marine primary productivity in the field: a comparison with conventional stimulated 'in situ' methods. Can. J. Fish. Aquat. Sci. 42: $864-872$

Hart, T. J. (1934). On the phytoplankton of the south-west Atlantic and Bellingshousen Sea. 'Discovery' Rep. 8: 3-268

Jassby, A. D., Platt, T. (1976). Mathematical formulation of the relationship between photosynthesis and light for phytoplankton. Limnol. Oceanogr. 21 540-547

Kottmeier, S. T., Sullivan, C. W. (1987). Late winter primary and secondary production in seawater west of the Antarctic Peninsula. Mar. Ecol. Prog. Ser. 36: 287-298

Krebs, W. W. (1983). Ecology of neritic diatoms, Arthur Harbor, Antarctica. Micropaleontology 29: 267-297

Lewis, M. R., Smith, J. C. (1983). A small volume, shortincubation-time method for measurement of photosynthesis as a function of incident irradiance. Mar. Ecol. Prog. Ser. 13: 99-102

Li, W. K. W. (1980). Temperature adaptation in phytoplankton; cellular and photosynthetic characteristics. In: Falkowski, P. G. (ed.) Primary productivity of the sea. Plenum Press, New York, p. 259-279

Neori, A., Holm-Hansen, O. (1982). Effect of temperature on rates of photosynthesis in Antarctic phytoplankton. Polar Biol. 1: 33-38

Palmisano, A. C., SooHoo, J. B., Sullivan, C. W. (1985). Photosynthesis-irradiance relationships in sea-ice microalgae from McMurdo Sound, Antarctica. J. Phycol. 21: 341-346

Palmisano, A. C., SooHoo, J. B., Sullivan, C. W. (1987). Effects of four environmental variables on photosynthesisirradiance relationships in Antarctic sea-ice microalgae. Mar. Biol. 94: 299-306

This article was submitted to the editor
Palmisano, A. C., Sullivan, C. W. (1983). Physiology of sea-ice diatoms. II. Dark survival of three polar diatoms. Can. J. Microbiol. 29: 157-160

Platt, T., Gallegos, C. L. (1980). Modeling primary production In: Falkowski, P. (ed.) Primary productivity in the sea Plenum Press, New York, p. 339-362

Platt, T., Gallegos, C. L., Harrison, W. G. (1980). Photoinhibition of photosynthesis in natural assemblages of marine phytoplankton. J. mar Res. 38: 687-701

Platt, T., Harrison, W. G., Irwin, B., Horne, E. P., Gallegos, C. L. (1982). Photosynthesis and photoadaptation of marine phytoplankton in the arctic. Deep Sea Res. 29: 1159-1170

Prézelin, B. B. (1981). Light reactions in photosynthesis. In: Platt, $T$ (ed.) Physiological bases of phytoplankton ecology. Can. J. Fish. Aquat. Sci. 210: 1-43

Rivkin, R. B., Putt, M. (1987). Diel periodicity of photosynthesis in polar phytoplankton: influence on primary production. Science 238: 1285-1288

Sakshaug, E., Holm-Hansen, O. (1984). Factors governing pelagic production in polar oceans. In: Holm-Hansen, $O$., Bolis, L., Gilles, R. (eds.) Marine phytoplankton and productivity. Springer-Verlag, Berlin, p. 1-18

Smith, W. O., Jr (1987). Phytoplankton dynamics in marginal ice zones. Oceanogr. mar Biol. A. Rev. 25: 11-38

Smith, W. O., Jr, Keene, N. K., Comiso, J. C. (1988). Interannual variability in estimated primary productivity of the Antarctic marginal ice zone. In: Saarhage, D. (ed.) Antarctic ocean and resources variability. Springer-Verlag, Berlin, p. 131-139

Smith, W. O., Jr, Nelson, D. M. (1986). The importance of iceedge phytoplankton blooms in the Southern Ocean. BioSci. 36: 251-257

Theodórsson, P., Bjarnasor, J. O. (1975). The acid-bubbling method for primary productivity measurements: modified and tested. Limnol. Oceanogr. 20: 1018-1019

Tilzer, M. M., Dubinsky, Z. (1987). Effects of temperature and day length on the mass balance of Antarctic phytoplankton. Polar Biol. 7: 35-42

Tilzer, M. M., Bodungen, B. von, Smetacek, V (1985). Light dependence of phytoplankton photosynthesis in the Antarctic Ocean: implications for regulating productivity. In: Siegfried, W. R., Condy, P. R., Laws, R. M. (eds.) Antarctic nutrient cycles and food webs. Springer-Verlag, Berlin, p. 60-69

Tilzer, M. M., Elbrächter, M., Geiskes, W. W., Beese, B. (1986). Light-temperature interactions in the control of photosynthesis in Antarctic phytoplankton. Polar Biol. 5: 105-111

Weber, L. H., El-Sayed, S. Z. (1987). Contribution of the net, nano- and picoplankton to the phytoplankton standing crop and primary productivity in the Southern Ocean. J. Plankton Res. 9: 973-994

Wilson, D. L., Smith, W. O., Jr, Nelson, D. M. (1986). Phytoplankton bloom dynamics of the western Ross Sea ice edge-I. Primary productivity and species-specific production. Deep Sea Res. 33: 1375-1387

Zimmerman, R. C., SooHoo, J. B., Kremer, J. M, D'Argenio, D.Z. (1987). An evaluation of variance approximation techniques for non-linear photosynthesis-irradiance models. Mar. Biol. 95: 209-215

Manuscript first received: June 20,1988

Revised version accepted: February 6, 1989 